\title{
Oscillation of water table due to rainfall: an experience of modeling in GIS
}

\author{
Bianca Federici ${ }^{1}$, Rossella Bovolenta ${ }^{1}$, Dario Balestrero ${ }^{1}$, Roberto Passalacqua ${ }^{1}$ \\ ${ }^{1}$ University of Genoa, Department of Civil, Chemical and Environmental Engineering, Italy \\ Corresponding author: \\ Bianca Federici ${ }^{1}$ \\ Email address: bianca.federici@unige.it
}

\begin{abstract}
A physically-based Integrated Hydrological-Geotechnical model (IHG) able to assess the rainfallinduced landslide susceptibility was developed, refined and applied in GIS environment along the past years (Passalacqua, 2002; Federici et al., 2014; Bovolenta et al., 2016), showing its reliability. It is a useful instrument to landslide susceptibility evaluations and land-use planning over wide areas. The present paper focuses on the modeling of water table oscillation due to rainfall, comparing different hydrological models.
\end{abstract}

Keywords: $\quad$ water table, groundwater, landslide, GIS

\section{INTRODUCTION}

To analyze and predict rainfall-induced landslides many models have been proposed in literature. The soil is usually assumed isotropic and homogeneous or, at least, horizontal heterogeneity is accounted for (e.g. Iverson, 2000; Baum et al., 2002; Montrasio \& Valentino, 2008). The water table is often modeled into a steady state or physically based models are adopted (e.g. Montgomery \& Dietrich, 1994; Wu \& Sidle, 1995; Iverson, 2000; Baum et al., 2002; Qiu et al., 2007; Lu \& Godt, 2008; Baum et al., 2010); because the computational effort is considerable, those models are poorly suited to analyze wide areas. Moreover, the two-dimensional landslide simulation approach by the limit equilibrium method is often unsuited to full basin analyses and, furthermore, to kinematic phenomena with pronounced three-dimensional character.

The Authors have developed a physically-based Integrated Hydrological-Geotechnical model (IHG), allowing the determination of the phreatic table's oscillation and then the slope stability analysis by the Skempton \& Delory's method applied to any pixel of the model (Passalacqua, 2002; Federici et al., 2014; Bovolenta et al., 2016). The results are rendered into raster maps.

The present paper focuses on the modeling of water table due to rainfall, comparing the IHG model with the groundwater flow model implemented in GRASS (r.gwflow). 


\section{MODELS AND DATA}

The IHG model and the r.gwflow have been recently applied to the benchmark site of Mendatica, in Western Liguria.

Mendatica is a village lying on the accumulation zone of a large relict landslide of about 250 hectares. The whole deposit is made up of several small bodies in active or quiescent landslide conditions, mainly reactivated because of intense rainfall events. Since 2006, investigations to support a more proper definition of the site's hydro-geological model have been conducted; they revealed an extremely heterogeneous composition of the soil deposit. The presence of areas with different permeability is responsible of a very complex underground hydrogeology, characterized by levels of groundwater at different depths, either interconnected or isolated.

The Digital Terrain Model and other cartographic data are available. The digital models of the bedrock and the average groundwater level were obtained, by Triangulated Irregular Network (TIN) interpolation, from scattered survey points and additional points set along the riverbeds (Figure 1).
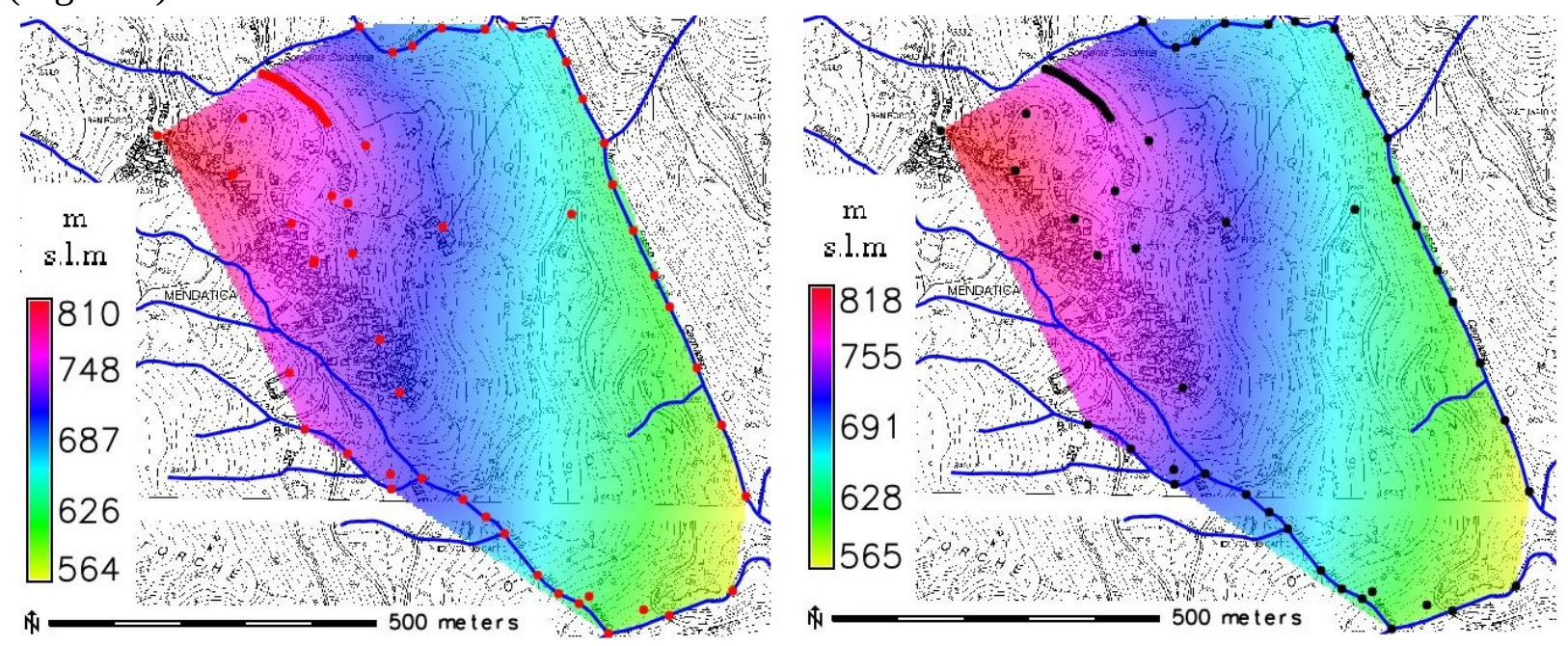

Figure 1. Digital model of the bedrock (left) and of the average groundwater table (right). The red dots represent the boreholes or emerging rock locations, the black ones show piezometers or wet riverbeds locations.

The r.gwflow model, available in GRASS GIS, consists in a numerical calculation program for transient, confined and unconfined groundwater flow. It is based on Darcy's law and a finite volume discretization allowing to consider homogeneous and anisotropic soils. The model calculates the piezometric head and the filter velocity field, starting from the raster maps illustrated in Figure 2, e.g. the hydraulic conductivity which is porosity dependent. 


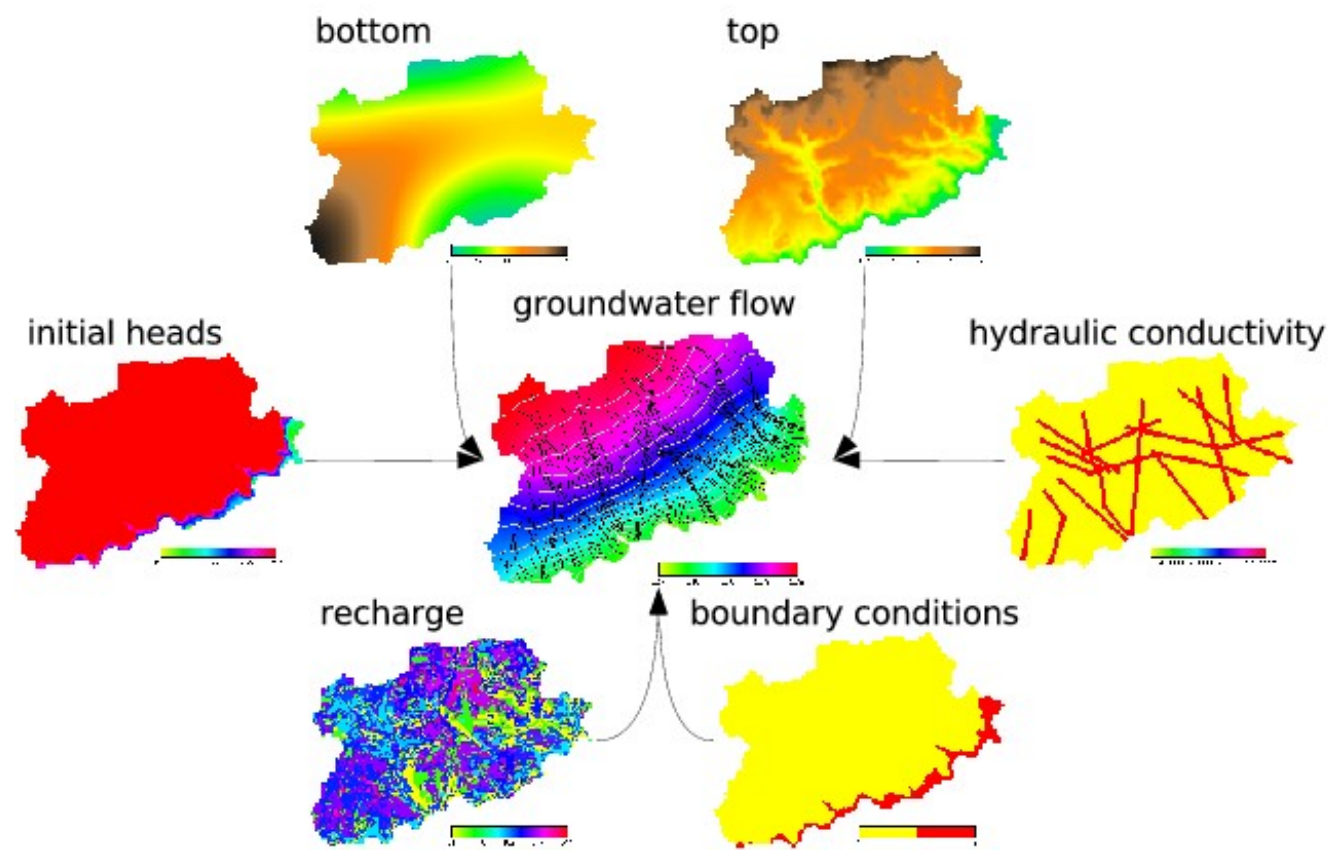

Figure 2. Workflow of r.gwflow (from: https://grass.osgeo.org/grass73/manuals/r.gwflow.html).

The IHG model runs, for each unit cell, a hydrological balance based on the modified Curve Number (CN) method (SCS, 1972-1975), in order to compute the evolution of groundwater level for any sequence of consecutive days of rain. It takes into account different soil moisture levels due to rainfall, using the equations provided by the SCS in function of the rainfall history of the previous days. It evaluates the $\mathrm{CN}$ for each cell and then the run-off, obtaining the infiltration quantity as difference. Then the IHG model treats each cell as an underground reservoir, with a maximum storage capacity equal to the potential maximum soil moisture retention (SCS, 19721975). The reservoir is fed by the portion of rain infiltrated into the ground, and emptied by both the subsurface flow and the evapotranspiration.

The subsurface flow is described by an exponential discharge function of the reservoir, ruled by the hydraulic conductivity, the slope gradient and the drainage length of each cell. The evapotranspiration (ET) assessment is very expensive, hence, the approximate method of Hargreaves \& Samani (1982) was implemented. It allows calculating the potential evapotranspiration (ETP) at standard conditions, as a function of air temperature only. At the moment the model doesn't considers the water lateral intakes; to overcome this, the Authors introduced also a "fictitious effective porosity", taking into account the interconnected void spaces that contributes to fluid flow and implicitly taking into account, for each pixel, the lateral intakes due to the groundwater flow. The values of the "fictitious effective porosity", calibrated starting from the oscillations measured by piezometers, depend on the soil, the rain intensity and on the thickness of the saturable layer between the ground level and the average groundwater level.

The workflow of IHG model is illustrated in Figure 3. 


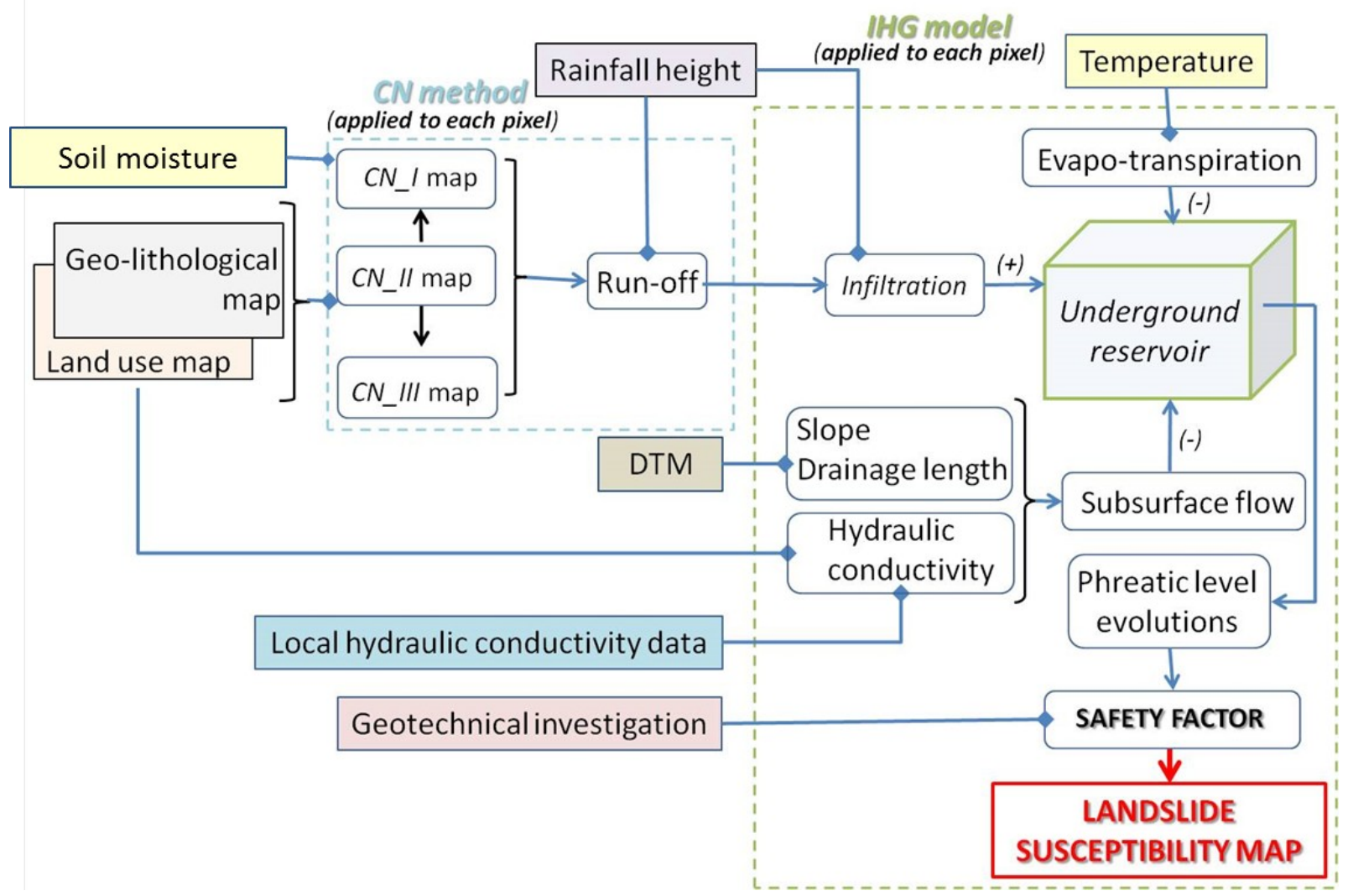

Figure 3. Workflow of IHG model.

\section{COMPARISONS}

The Authors applied the IHG and r.gwflow models to Mendatica site in relation either to an intense and to a moderate rain.

The models, although based on different theories, start from the same initial data (such as the raster maps of bedrock, average groundwater level and rainfall) except for the porosity differently defined. The introduction into the IHG model of the fictitious effective porosity, spatially variable in function of the deposit's thickness (Figure 4), leads to outputs of IHG model more coherent to the site data, especially during intense rainfall events. In fact the fluctuations of groundwater level observed in the piezometers vary widely in time but also between neighboring points (Figure 5).

Figure 6 shows the phreatic table variations with respect to the average groundwater level at the end of an intense rainfall event (from the $4^{\text {th }}$ to the $15^{\text {th }}$ of January 2008). Note that the IHG model produces greater values of the groundwater level variation than r.gwflow model does, coherently with the piezometrical data measured in site. 


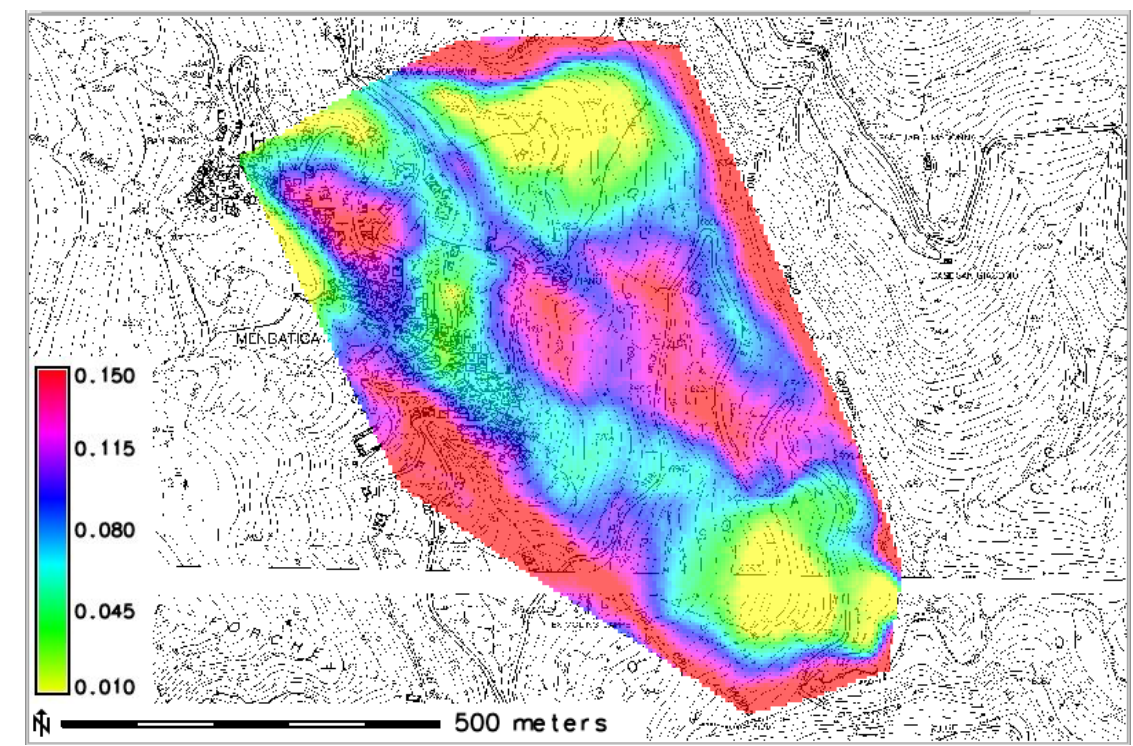

Figure 4. Fictitious effective porosity map for intense rainfall events.
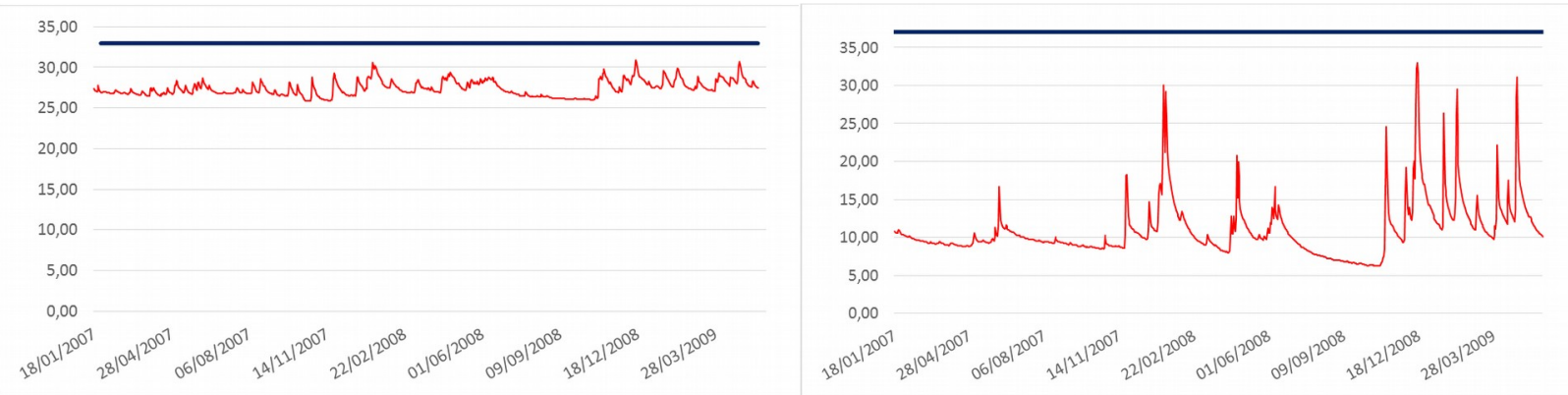

Figure 5. Example of phreatic table variations in time observed in two neighboring piezometers; the red and blues lines indicates the heights (in $\mathrm{m}$ ) of water table and of ground surface with respect to bedrock respectively.
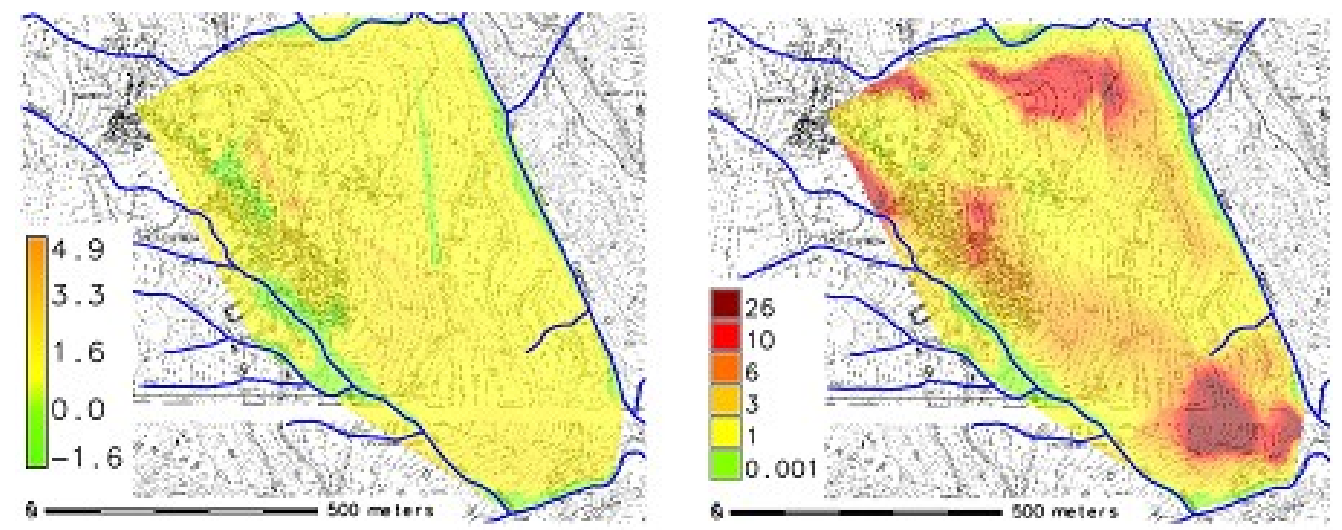

Figure 6. Groundwater level variations (in $\mathrm{m}$ ) with respect to the average groundwater level at the end of an intense rainfall event (from the $4^{\text {th }}$ to the $15^{\text {th }}$ of January 2008), evaluated by r.gwflow (left) and IHG model (right). 


\section{CONCLUSIONS}

The present paper has focused the attention on the modeling of water table oscillation, comparing the IHG model, proposed by the authors, with the r.gwflow model implemented in GRASS GIS. Their application to the complex underground hydrogeology of Mendatica site leads to outputs more coherent to the site data for the IHG model, especially during intense rainfall events, thanks to the fictitious effective porosity. A deeper comparison between the two models and with other ones will be performed in the near future.

\section{ACKNOWLEDGMENTS}

Thanks are due to the Technicians working for the Comune of Mendatica, who made available the full range of the data sets and offered their complete assistance during the Authors' terrain surveys/reckons.

\section{REFERENCES}

Baum R.L., Savage W.Z., Godt J.W. 2002. TRIGRS-A Fortran Program for Transient Rainfall Infiltration and Grid-Based Regional Slope-Stability Analysis, USGS Open-File Report 02424.

Baum R.L., Godt J.W., Savage W.Z. 2010. Estimating the timing and location of shallow rainfallinduced landslides using a model for transient, unsaturated infiltration. Journal of Geophysical Research: Earth Surface. Vol. 115 (F3).

Bovolenta R., Passalacqua R., Federici B., \& Sguerso D. 2016. LAMP Landslide Monitoring and Predicting for the analysis of landslide susceptibility triggered by rainfall events. 12th International Symposium on Landslides (ISL2016) 12th-19th June in Naples, Italy, 2:517-522.

Federici B., Bovolenta R., Passalacqua R. 2014. From rainfall to slope instability: an automatic GIS procedure for susceptibility analyses over wide areas. Geomatics, Natural Hazards \& Risk, Special Issue, ISSN: 1947-5713, doi: 10.1080/19475705.2013.877087.

GRASS Development Team, 2015. Geographic Resources Analysis Support System (GRASS) Software, Version 7.0. Open Source Geospatial Foundation. http://grass.osgeo.org

Hargreaves G. H, Samani Z. 1982. Estimating potential evapotranspiration. Journal of irrigation and drainage engineering, 108(3):223-230, ASCE library.

Iverson R.M. 2000. Landslide triggering by rain infiltration. Water Resources Research, 36: 1897-1910.

Lu N., Godt J. 2008. Infinite slope stability under steady unsaturated seepage conditions. Water Resources Research, vol. 44, W11404, doi:10.1029/2008WR006976.

Montgomery D.R., Dietrich W.E. 1994. A physically based model for the topographic control on shallow landsliding. Water Resources Research, 30 (4): 1153-1171.

Montrasio L., Valentino R. 2008. A model for triggering mechanisms of shallow landslides. Natural Hazards and Earth System Sciences, 8: 1149-1159, doi:10.5194/nhess-8-1149-2008.

Passalacqua R. 2002. Vulnerabilità territoriale da frane e crolli in roccia, UE INTERREG II - 
Project GE.RI.A., Dossier Tematico ${ }^{\circ}$ 8, Collana Territorio e Ambiente, Ed. del Delfino Moro, Albenga (SV), ISBN 88-88397-05-1, pp. 1-37.

Skepton A.W., Delory F.A. 1957. Stability of natural slopes in London Clay. In Proc. 4th Int. Conf. Soil Mech. 2: 378-381.

Qiu C., Esaki T, Xie M., Mitani Y., Wang C. 2007. Spatio-temporal estimation of shallow landslide hazard triggered by rainfall using a three-dimensional model. Environ Geol. 52: 1569-1579.

SOIL CONSERVATION SERVICE 1972. Hydrology. In: National Engineering Handbook section 4, U.S. Dept. of Agriculture (available from the U.S. Government Printing Office), Washington D.C. - USA.

SOIL CONSERVATION SERVICE 1975. Urban hydrology for small watersheds. Tech. Rel. No. 55, U.S. Dept. of Agriculture, Washington D.C. - USA.

Wu W., Sidle RC. 1995. A Distributed Slope Stability Model for Steep Forested Basins. Water Resources Research, 31 (8): 2097-2110. 